\title{
KONSTRUKSI EKSISTENSIAL DALAM BAHASA DEVAYAN SIMEULUE-ACEH
}

\author{
Restria Mulyani ${ }^{1)}$, Mulyadi ${ }^{2)}$ \\ ${ }^{1}$ Fakultas Ilmu Budaya, Universitas Sumatera Utara \\ email: restriamulyani20@gmail.com \\ ${ }^{2}$ Fakultas Ilmu Budaya, Universitas Sumatera Utara \\ email: mulyadi.usu@gmail.com
}

\begin{abstract}
Abstrak
Konstruksi eksistensial adalah konstruksi yang digunakan untuk menyatakan keberadaan seseorang atau sesuatu. Penelitian ini bertujuan untuk mengungkap bagaimana penggunaan konstruksi eksistensial dalam bahasa Devayan Simeulue-Aceh dan bahasa Inggris dibentuk berdasarkan ciri umum: 1. definiteness restriction dan 2. predicate restriction serta bagaimana penggunaan pola struktur konstruksi existensial yaitu expletive (eksistensial ada), Copula (CL) 'adalah, ialah merupakan', Pivot (NP) dalam kalimat yang menggunakan bahasa Devayan Simeulue-Aceh yang dibandingkan dengan bahasa Inggris. Konstruksi eksistensial dalam bahasa Devayan Simeulue-Aceh ditandai dengan ' $n g a$ ' dan 'alek'.
\end{abstract}

Kata Kunci: konstruksi eksistensial, bahasa Devayan Simeulue-Aceh.

\section{Abstract}

The existensial construction refers to construction expressing a proposition about the existence or presence of someone or something as exemplified. This study aims to reveal how the Devayan Simeulue-Aceh language and English language were formed in existensial construction in two general distinctive features: 1. definiteness restriction and 2. predicate restriction. How to use The structure of existensial construction formed by expletive (eksistensial ada), Copula (CL) 'adalah, ialah merupakan', Pivot (Np) in Devayan Simeulue-Aceh language. Existensial construction in Devayan Simeulue-Aceh language signed by 'nga' and 'alek'.

keywords: existensial construction, Devayan Simeulue-Aceh language.

\section{PENDAHULUAN}

Bahasa Devayan Simeulue-Aceh adalah salah satu bahasa daerah yang dipergunakan oleh masyarakat yang mendiami pulau Simeulue. Bahasa Simeulue masih dipelihara oleh masyarakat pemakainya dengan baik dan dapat memenuhi kebutuhan pemakainya sebagai alat pengungkap pikiran dan perasaannya dalam kehidupan sehari-hari. Bahasa Devayan adalah salah satu bahasa asli dipulau Simeulue. Bahasa ini termasuk salah satu bahasa minoritas di provinsi Aceh, Indonesia. Bahasa ini dituturkan pada 7 wilayah kecamatan dari 10 kecamatan dipulau ini dengan jumlah penduduk 59.904 jiwa.

Bahasa Devayan kini dipergunakan oleh lebih kurang 40.000 orang penduduk pulau Simeulue yang mediami daerah Kecamatan Simeulue Timur, Kecamatan Simeulue Tengah, dan Kecamatan Teupah Selatan. penduduk Simeulue lainnya yaitu yang mendiami Kecamatan Simeulue Barat dan Kecamatan Salang menggunakan bahasa Sigulai bahasa Devayan sebuah bahasa yang dituturkan oleh suku Devayan yang mendiami pulau Simeulue bagian Tengah Selatan, yaitu Kecamatan Simeulue Cut, Simeulue Timur, Simeulue Tengah, Teupah Barat, Teupah Tengah, Teupah Selatan dan Teluk Dalam.

Bahasa Devayan dan bahasa Indonesia saling mempengaruhi. Weinrinch (dalam Chaer 2007:65) mengartikan kontak bahasa adalah pemakaian dua bahasa oleh seseorang secara bergantian. Artinya unsur-unsur bahasa Devayan dipakai ketika menggunakan bahasa Indonesia, begitu juga sebaliknya.

Kim, Jong-Bok. 2013 dalam penelitiannya telah menemukan tiga struktur eksistensial dalam bahasa Inggris: klausa kecil, bare-NP, dan analisis terner. Masing-masing memiliki bentuk yang berbeda dilihat dari segi sintaksisnya, penulis makalah ini mengulas secara kritis ketiga analisis sebelumnya dan 
menawarkan analisis hibrida yang memungkinkan keduanya sebagai Noun Phrase (NP) dalam menganalisis tata bahasa konstruksi.

\section{a. Konstruksi eksistensial dalam bahasa Devayan}

Konstruksi eksistensial adalah konstruksi yang digunakan untuk menyatakan keberadaan seseorang atau sesuatu. Konstruksi eksistensial dalam bahasa Inggris ditandai dengan kata "there". Konstruksi eksistensial memiliki ciri dan tanda khusus dalam konstruksi, ada dua ciri khusus konstruksi eksistensial menuru Mc Nally 2011, More 1997, Bentley et al 2013 Mc Closkey 2014,a.o) yang sering dihubungkan dengan struktur bahasa, yaitu Definitness Restriction dan Predicate Restriction.

Dalam bahasa Devayan konstruksi eksisitensial ditandai dengan kata "nga" dan "alek". "nga " yang menunjukkan keberadaaan seseorang/sesuatu, sementara eksistensial "alek" untuk menyatakan apa yang ada pada orang tersebut dan menunjukkan kepunyaan.

Dalam Bahasa Inggris Konstruksi eksistensial ditandai dengan kata "there" yang dikenal dengan "existential there" (Richard Nordquist, (2018) yang kata kerjanya sering diikuti oleh tobe contohnya:

1. There was a telephone

2. There were lots of people in town

3. Rick, there are many exit visas sold in this café (Captain Reanult,Casablanca)

Dalam bahasa Devayan Simeulue-Aceh, terdapat juga konstruksi eksistensial yang ditandai dengan kata " $n g a$ " yang berarti ada. contohnya:

1. Nga kopi mo dok detak meja

'Ada kopi diatas meja'

2. Nga mayal dok bak afu

'Ada kucing didapur'

3. Nga hepeng mo balal ere?

'Ada uangmu hari ini?'

Dari tiga contoh di atas, diketahui bahwa subjek nga 'ada' memiliki potensi untuk bergabung dengan verbalain membentuk konstruksi eksistensial. Selain subjek $n g a$, ada juga subjek lain dalam bahasa Devayan
Simeulue-Aceh yang membentuk konstruksi eksistensial, tetapi tidak seproduktif subjek nga, yaitu subjek alek' bersama dan ada'.

Artikel ini akan membahas konstruksi eksistensial dalam bahasa Devayan-Simeulue Aceh berdasarkan karakteristik ciri umum konstruksi eksistensial, dan pola pembentuk konstruksi eksistensial dalam data yang ditemukan.

\section{METODE PENELITIAN}

Jenis penelitian ini adalah kualitatif. Sumber data yang diperoleh dari tuturan langsung pengguna bahasa Devayan SimeulueAceh. Ada tiga tahapan yang ditempuh dalam kajian ini, yaitu tahapan pengumpulan data, analisis data, dan penyajian hasil analisis data. Pada setiap tahap digunakan metode tertentu. Pada tahap pengumpulan data digunakan metode simak atau metode observasi. kemudian mencatat kalimat yang mengandung konstruksi eksistensial. Data yang berupa kalimat yang mengandung konstruksi eksistensial kemudian diklasifikasikan menurut (1) karakteristik ciri umum konstruksi eksistensial dan (2) struktur pola pembentuk konstruksi eksistensial dalam bahasa Devayan Simeulue-Aceh.

Data dianalisis dengan metode agih, yaitu metode yang alat penentunya berupa bahasa itu sendiri. Metode agih ini diterapkan dengan teknik lesap, teknik sisip, teknik perluas, dan teknik balik (Sudaryanto, 1993:36).Dalam menyajikan hasil analisis data, digunakan metode informal. Penyajian hasil analisis data secara informal adalah penyajian hasil analisis dengan menggunakan kata-kata biasa.

\section{HASIL DAN PEMBAHASAN}

a. Karakteristik konstruksi eksistensial dalam bahasa Devayan Simeulue-Aceh Karakteristik struktur konstruksi eksistensial dalam bahasa Devayan SimeulueAceh berdasarkan ciri umum sebagai berikut. (1) Definiteness Restriction digunakan untuk menyatakan kepastian dari sebuah keberadaan 
(2) Predicate Restriction untukmenyatakan kebenaran dari predikat yang dijelaskan

\section{b. Ciri konstruksi eksistensial Definiteness Restriction}

Konstruksi eksistensial dalam bahasa Devayan Simeulue-Aceh berdasarkan ciri Definiteness Restriction, contohnya:

1) Nga Manok ek bahak batek

'Ada ayam di dalam kandang'

Konstruksi eksistensial pada contoh (1) adalah nga sebagai expletive yang menjelaskan keberadaan dari pivot manok dan coda dari kalimat diatas adalah ek bahak batek

Apabila unsur eksistensial yang menyatakan keberadaan di pindahkan letaknya menjadi predikat dalam bahasa Devayan SimeulueAceh menjadi

\section{2) Manok nga ek bahak batek}

'ayam ada didalam kandang'

Perubahan penempatan expletive dalam bahasa Devayan Simeulue-Aceh tidak merubah makna dan tujuan dari kalimat yang disampaikan.

\section{c. Ciri konstruksi eksistensial Predicate Restriction}

Konstruksi eksistensial dalam bahasa Devayan Simeulue-Aceh berdasarkan ciri Predicate Restriction, contohnya.

1) Nga murid singa pandai ek bahak kelas mo?

'Adakah siswa yang pandai dikelas mu?'

2) Alek kamar singa kosong ek luma mo?

'Adakah kamar yang kosong dirumah mu?'

Letak predikat restriction konstruksi eksistensial pada contoh (1) nga sebagai kalimat tanya untuk membuktikan predikat siswa yang pintar yang ingin ditanyakan keberadaannya. jika ingin menanyakan berapa jumlah siswa yang pintar dikelas mu, dalam bahasa Devayan Simeulue-Aceh menggunakan kata ofel 'berapa'.

(a) Ofel murid singa pandai ek bahak kelas mo?

'Berapa jumlah siswa yang pintar dikelas mu?'

(b) Ofel kamar singa kosong ek luma mo?
'Berapa jumlah kamar yang kosong dirumah kamu?'

Dalam kalimat (a) terdapat perbedaan dalam menyatakan predikat restriction dalam bahasa Devayan Simeulue-Aceh yang menanyakan jumlah siswa, penggunaan nga pada contoh (1) dan ofel pada contoh (a) begitu juga pada contoh (2) nga menanyakan keberadaan dan (b) ofel menanyakan jumlah, yang berbeda penggunaanya pada bahasa Inggris.

\section{d. Struktur pola pembentuk konstruksi eksistensial dalam bahasa Devayan Simeulue-Aceh.}

Terlepas dari karakteristik unik konstruksi eksistensial, studi tentang kalimat eksistensial tidak banyak dikaji, baik dalam bahasa Indonesia khususnya bahasa Devayan Simeulue-Aceh atau di luar bahasa Indonesia (bahasa Inggris). Struktur pola konstruksi eksistensial yaitu expletive (eksistensial ada), Copula (CL) 'adalah, ialah merupakan', Pivot (NP)

Beberapa ahli bahasa dari Malaysia, yang karya-karya nya sering disebut Asmah (1980) dan Nik Safiah et al. (1993), tidak menyadari masalah kalimat eksistensial dan kata kerja pivot. Namun, kata kerja ada 'tobe / have', yang merupakan anggota kata kerja pivot, telah dipelajari oleh beberapa ahli bahasa. Mashudi (1981: 53) mengklasifikasikan fungsi ADA menjadi dua:

1) Sebagai kata kerja posesif yang kira-kira setara dengan bahasa Inggris 'untuk memiliki'

2) Sebagai morfem kira-kira setara dengan bahasa Inggris 'tobe', yang oleh Ramli (1989: 82) disebut copula ada.

Contohnya dalam bahasa Devayan SimeulueAceh:

1) Ali nga dufo mayal ne

'Ali ada dua-ekor kucing'

2) Budi nga riak luma dumaar

'Budi ada dirumah sekarang'

Ramli (1989:82-84) menunjukkan tiga perbedaan antara copula dan possessive 'ada' yaitu pembentuk konstruksi eksistensial yang 
diikuti dengan Noun Phrase (NP), Adjective Phrase (AP), PrepositionPhrase (PP)

Contoh pola konstruksi eksistensial dengan AP dan PP nga 'ada':

1) Ahmad nga ya mahenong

'Ahmad ada-lah' [AP kurus]

2) Alisha nga dok Pustaka

'Alisha ada' [PP di perpustakaan]

Contoh pola konstruksi eksistensial possessive nga 'ada':

1) Dinda nga sao Mobil

'Dinda ada' [NP se-buah mobil]

2) Ahmad nga riak sekolah

'Ahmad ada' [PP di sekolah]

\section{KESIMPULAN}

Konstruksi eksistensial berfungsi untuk menyatakan informasi yang menunjukkan kondisi yang sebenarnya yang identik dengan kata ada. Konstruksi eksistensial memiliki dua ciri umum yaitu: a. Definiteness Restriction dan b. Predicate Restriction yang penggunaanya berbeda dalam bahasa Devayan Simeulue-Aceh saat menanyakan ada $n g a$ dan ofel menanyakan jumlah dari sebuah keberadaan.

Struktur pola konstruksi eksistensial terdiri dari expletive (eksistensial ada), Copula (CL) 'adalah, ialah merupakan', Pivot (Np). Konstruksi eksistensial dalam bahasa Devayan ditandai dengan $n g a$ ' $A d a$ ' sedangkan dalam bahasa Inggris digunakan there untuk menunjukan konstruksi eksistensial.

\section{REFERENSI}

Asmah Hj. Omar. 1980. Nahu Melayu Mutakhir [Modern Malay Grammar]. Kuala Lumpur: Dewan Bahasa dan Pustaka.

Bentley, D., F .M. Ciconte and S. Cruschina (2013) Existential constructions in crosslinguistic perspective. Italian Journal of Linguistics 25(1):1-13.

Chaer, Abdul. 2007. Linguistik Umum cetakan ketiga. Jakarta: Rineka Cipta.
Kim, Jong-Bok. 2013. On the Structure of the Existential Construction: A Hybrid Analysis. Studies in Modern Grammar 72, 17-39

Mashudi Kader. 1981. The Syntax of Malay Interrogatives. Kuala Lumpur: Dewan Bahasa dan Pustaka.

McCloskey, J. (2014) Irish Existentials in Context. Syntax 20140:4, 343-384.

McNally, L. (2011) Existential sentences. In: von Heusinger, Maienborn and Portner (eds).

Nadiah Zainal Abidin English To Malay (Bahasa Melayu) Translation: Syntactical Issues Involving Time Reference (Language Department, Universiti Teknikal Malaysia Melaka, Malaysia).

Sara Thorne, Mastering advanced English Language. Palgrave Macmillan, 2008 Semantics (HSK 33.2). Berlin, de Gruyter, 1829-1848. Moro, A. (1997) The raising of predicates. Cambridge, CUP.

Sudaryanto. 1993. Metode dan Aneka Teknik Analisis Bahasa. Yogyakarta: Duta Wacana University Press. 